\title{
The use of blood equol values in devising grazing management strategies for red clover-based pastures
}

\author{
R.G. KEOGH', R. KRAMER ${ }^{2}$, M.F. MCDONALD', ANGELA BLEWMAN ${ }^{3}$ and JANE CRABB2 \\ 'Agresearch Grasslands, PB I 1008, Palmerston North \\ ${ }^{2}$ Animal Science Department, Massey University, Palmerston North \\ "Livestock Improvement Corporation, PB 3016, Hamilton
}

\section{Abstract}

Feeding and grazing trials were carried out to establish relationships between formononetin intakes and blood equol levels, and to characterise the build-up and clearance of free and conjugated equol in the blood of sheep feeding on either high (Grasslands Pawera) or low (G27) formononetin red clovers. In the feeding trials, blood equol levels were positively correlated with formononetin intakes, and levels peaked at 2-4 hours after feeding. In the grazing trial, groups of 10 sheep grazed either Pawera or G27 red clover pastures for 1-, 2-, or 3-week periods while a control group was on grass-dominant pasture. Analysis of blood equol showed differences in the rates of accumulation and in the mean blood concentrations. Free equol was present in the blood of sheep after one day of grazing on Pawera whereas it was not detected in blood of sheep on G27 until 5 days after grazing began. Blood equol rose to equilibrium levels and remained thus until sheep were removed from the red clovers. The concentrations of equol in Pawera ewes were approximately three times those-in-G27-ewes. Free equol was rapidly cleared from the blood and was below the limit of detection by day 2 after transfer to a ryegrass pasture. The 4 day lag between start of grazing and the appearance of free equol in the blood of ewes on G27 offered scope for devising grazing management strategies which might enable use of G27 for flushing without an adverse effect on fertility. Results of trials in 1995 and 1996, in which ewes grazed alternately for 3.5 or 3 days on G27 and then for 3.5 or 4 days on grass pastures (per week) for 4 weeks before and during a 4-week mating period showed that the reproductive performance of ewes was unaffected. Such on/off systems of grazing management, therefore, enable G27 to be grazed safely by ewes around the time of mating.

Keywords: equol, ewe fertility, flushing, formononetin, grazing management, oestrogenic compounds, Trifolium pratense

\section{Introduction}

Red clover (Trifolium pratense) is a valuable forage legume that has the potential to contribute to higher warm season pasture yields and better livestock performance. Use of this legume has, however, been severely limited owing to (a) a general lack of persistence of some red clover cultivars in grazed pastures (Lancashire 1985) and (b) a potential risk of reproductive problems (Kelly et al. 1979; Shackell et al. 1993). Persistency has been improved by development of disease resistant (Anderson 1978) and stoloniferous cultivars (Smith \& Bishop 1993) and by better use of management techniques and companion species (Hay 7 Ryan 1989). Management strategies that allow seed production to increase soil seed reserves of the target species may further enhance persistency.

The development of widespread reproductive problems in ewes grazing subterranean clover pastures in Western Australia (Bennetts et $a /$. 1946) and subsequent research findings have been well documented (e.g., see reviews by Rossiter 1970; Shutt 1976; Cox 1978; Adams 1989: Davies 1987). Infertility was linked to the presence of oestrogenic compounds, of which-.. formononetin, biochanin $A$, and genistein predominated in subterranean clover foliage (Beck 1964) and in combined amounts of up to $5.6 \%$ of the plant dry weight. These compounds are isoflavones and possess only weak oestrogenicity (about $10^{.5}$ to $10^{-6}$ times as active as oestradiol) compared with the steroidal oestrogens, but derive their oestrogenic effects because of the large amounts ingested (Collins \& Cox 1985). These isoflavones are also present in other forage legumes, 'including red clover and white clover (Keogh 1995). Oestrogenic effects have-been-induced-in-sheep-grazing red clovers in New Zealand (Chang 1961: Kelly et al. 1979; Anwar 1994).

Oestrogenic effects in sheep were linked to the formononetin content of different subterranean clover strains but not to biochanin A or genistein levels (Millington et al. 1964). Subsequent metabolic studies showed that the 5-hydroxy isoflavones. biochanin A and genistein, are degraded to non-oestrogenic phenols (principally p-ethyl phenol), but that formononetin (of the 5-deoxy group). which has only very weak 
oestrogenicity. is converted via daidzein to equol, which is oestrogenically active (Shutt \& Braden 1968). So the oestrogenicity of formononetin is due largely to equol formed (from formononetin) in the rumen from whence it is readily absorbed (Shutt $e t$ al. 1970). with levels of up to $3-5 \mu \mathrm{g} / \mathrm{ml}$ (equol) present in blood plasma. The isoflavones and equol are in blood predominantly as conjugates - mostly glucuronides (Shutt et al. 1967) and small amounts as sulphoconjugates - with only 1$2 \%$ present in an unconjugated ("free" or biologically active form). The presence of "free" equol in the blood is, therefore. seen as important in the production of an oestrogenic response.

The development and use of low-formononetin cultivars of subterranean and red clovers has been an important means of helping to reduce reproductive problems associated with the "high oestrogen" clovers (Adams 1989). This development was facilitated in subterranean clover. as many existing varieties contained low levels of formononetin at the outset (Francis \& Millington 1965). In red clovers sufficient genotypic variation existed to enable selection and breeding of cultivars with low formononetin levels (Francis \& Quinlivan 1974: Rumball et al. 1996). Grasslands G27 red clover is a low formononetin selection from within Grasslands Pawera, a highly productive and persistent late-flowering. tetraploid that has high levels of formononetin (Kelly et al. 1979).

Options to minimise or prevent reproductive problems for livestock include:

1. use of "low oestrogen" cultivars

2. avoid grazing oestrogenic pastures, especially at critical periods such as before and during mating

3. incorporation of "high oestrogen" clovers (such as Pawera) in pasture mixtures to effectively dilute (reduce) formononetin intake

4. use of management strategies designed to minimise risks involved in grazing oestrogenic pastures.

This paper addresses the first and last of these options, and comprises two phases: (a) characterisation of the accumulation of equol in the blood of sheep feeding on red clover and its clearance from the blood after red clover feeding has ceased; and (b) the testing of an hypothesis based on results from (a).

\section{Methods}

(a) Feeding trials in which different quantities of freshly cut red clover were fed to sheep so that a range of formononetin intakes were achieved, and determination of equol levels in the blood serum at 3 times over the ensuing 24 hours.
A grazing trial was conducted in March-April 1994 to characterise the accumulation and clearance of both "free" and conjugated equol in blood plasma of ewes grazing G27, Pawera, or ryegrass pastures. Groups of 10 mixed age Romney ewes grazed the red clover pastures for 3,2 , or 1 weeks before mating, with the control group, on ryegrass-based pastures. Blood samples for equol determinations were taken throughout the treatment periods and for a further 2 weeks after removal to the ryegrass pastures. Information on mating dates and returns to service was recorded, and ovulation rates determined by laparoscopy.

Processing and extraction of blood samples, and equol determinations by HPLC were carried out using methods described by Kramer et al. (1996).

(b) Two trials were carried out to test the hypothesis that intermittent, or on/off systems of utilising red clovers have the desired effect of preventing accumulation of free equol, and thus reducing oestrogenicity.

Trial 1 was carried out in 1995 at the AgResearch Aorangi Lowland Research Farm in the Manawatu. A group of 25 two-tooth Romney ewes were alternated between G27 red clover and perennial ryegrass-white clover pastures -3.5 days on and 3.5 days off red clover per week starting mid-February. A control group of 25 ewes remained on the ryegrass-white clover pastures throughout. A further group of 5 ewes alternated between Pawera red clover and ryegrass-white clover pastures. Blood samples were taken regularly and analysed for free and total (free + conjugated) equol.

Trial 2 was conducted at Aorangi Research Farm in 1996. Two of three groups of 30 four-tooth Romney ewes were alternated between either G27 or Pawera and grass-based pastures, and the third group remained on ryegrass-dominant pastures throughout. A system of 3 days on red clover followed by 4 days off was adopted for this trial, which began in mid February. Mating took place over two oestrous cycles from mid March to mid April and the same information was recorded as for Trial 1.

\section{Results and discussion}

(a) A set of results from one of the feeding trials with Pawera red clover is shown in Figure 1.

There is a clear relationship between formononetin intake and serum equol concentrations. Moreover, equol is present in the blood very soon after feeding and reaches a maximum within 4 hours before dropping to almost zero levels after 24 hours. The maintenance of equol 
levels in the blood is, therefore, very dependent on continued ingestion of red clover (and formononetin).

Figure 1 Changes in total equol levels in blood serum at 0.5 hours, 2 hours, 4 hours, and 24 hours after feeding Pawera red clover to sheep.

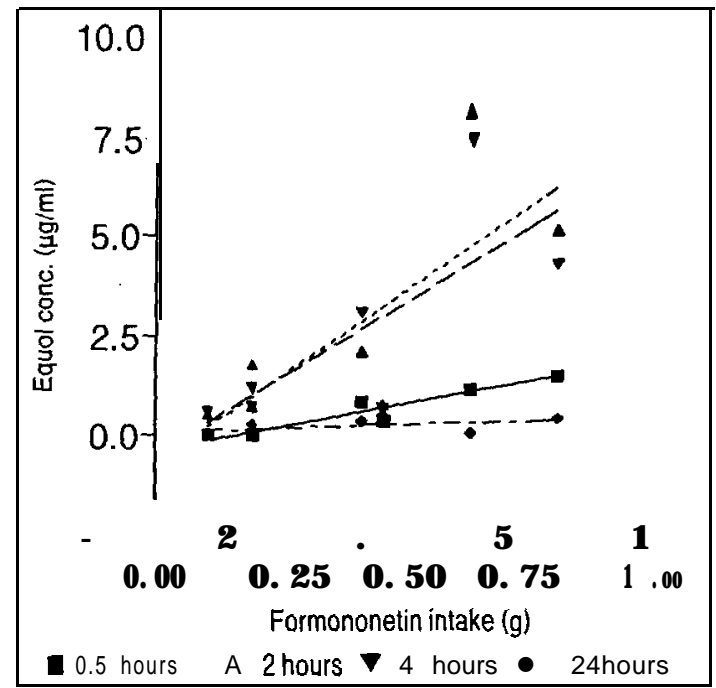

In the grazing trial formononetin levels in G27 and Pawera forages averaged $0.25 \%$ and $0.55 \%$ respectively. Equol results from this trial are in Figures 2 and 3. Conjugated equal was present in bloods of ewes on both red clovers from day 1 . The levels in the Pawera ewes were, however-significantly_higher than those in G27 ewes - averaging $23.7 \pm 2.94 \mu \mathrm{g} / 100 \mathrm{ml}$ and $7.8 \pm 2.19 \mu \mathrm{g} / 100 \mathrm{ml}$ respectively.

Free equal was present in the blood of Pawera ewes from the second day and averaged $1.04 \pm 0.25 \mu \mathrm{g} / 100 \mathrm{ml}$

Figure 2 Mean conjugated equol levels (+ SE of mean) in blood of ewes grazing Pawera or G27 red clovers.

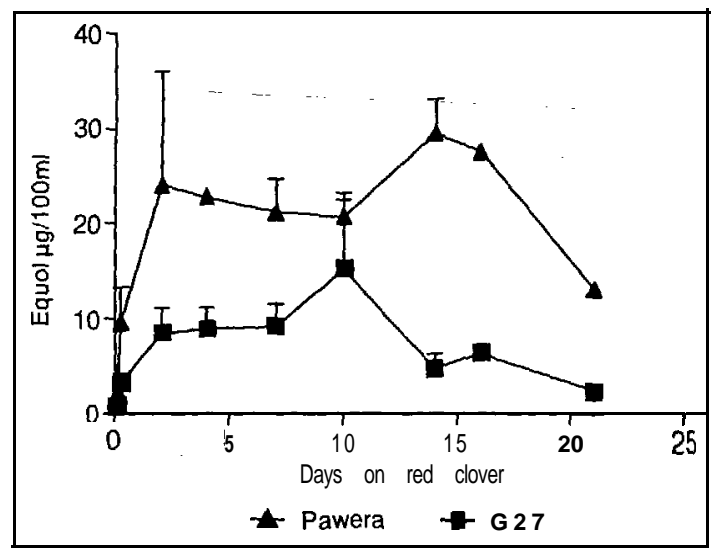

until removal from red clover. By contrast free equol was not detected in the blood of G27 ewes until after 4 days on red clover and averaged $0.36 \pm 0.09 \mu \mathrm{g} / 100 \mathrm{ml}$ (Figure 3). Both conjugated and free equol fractions were rapidly cleared from the blood - equal was not detectable on the second day after the sheep were removed from the red clover pastures.

Figure 3 Mean free equol levels ( + SE of mean ) in blood of ewes grazing Pawera and G27 red clovers.

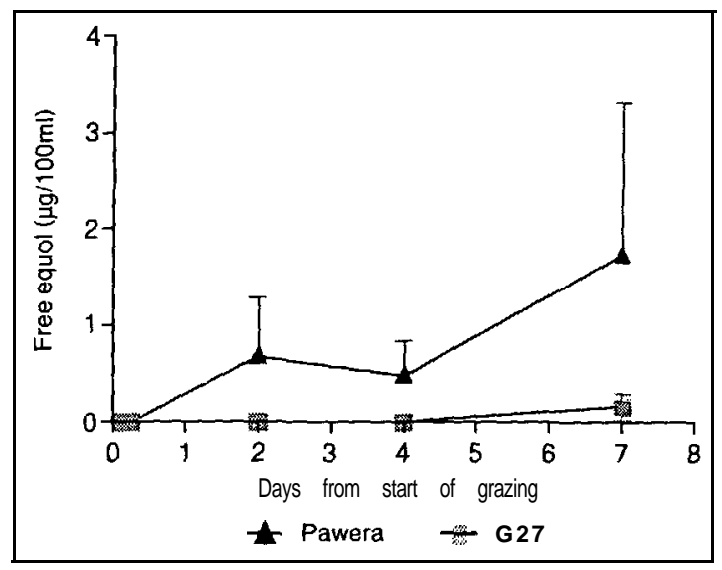

The most important result was the delay in the appearance of free equal in the blood of the G27 ewes until between the fourth and sixth day after the start of grazing. This delay, coupled with the rapid clearance of equal when red clover is removed from the diet, provides an obvious option that-might-lead-to-the safer_use of G27 red clover by ewes before, and even during, mating. The option is to adopt an on/off grazing system in which the ewes spend up to four consecutive days on G27 and are then grazed for several days on red cloverfree pastures.

(b) Trial 1 equol results are given in Figure 4 .

The conjugated equal rapidly accumulated in the blood within 24 hours of the start of grazing on the red clovers and was just as rapidly cleared from the blood within 24 hours of transference to ryegrass-white clover pastures. The conjugated equal levels were higher for the Pawera than for the G27 ewes. Free equal was not detected at any stage in blood samples taken while the ewes were grazing the red clovers.

There were no significant differences between the G27 and control ewes in either ovulation rates or in the number of lambs carried per ewe as determined at pregnancy scanning carried out 11 weeks after mating. 
Figure 4 Conjugated equol levels in ewes grazing Pawera or G27 red clovers during the on/off grazing trial 1995.

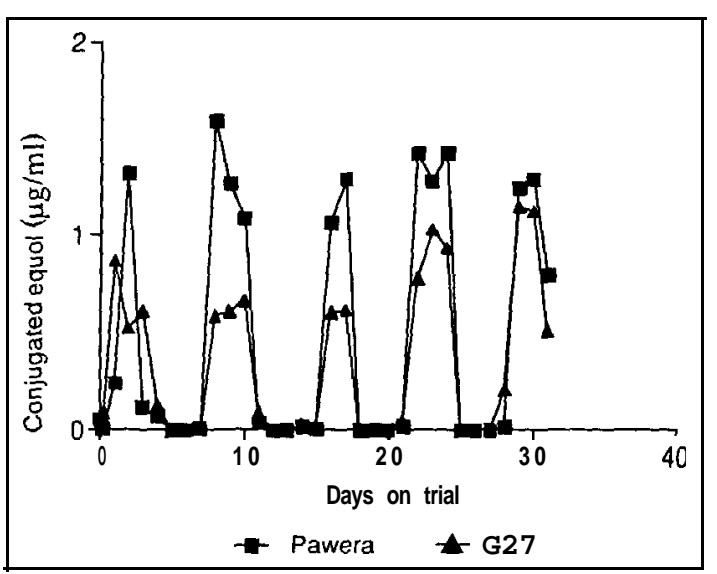

In Trial 2 the formononetin in the forage averaged $0.3 \%$ and $0.45 \%$ for G27 and Pawera respectively. Plasma equol results are not yet available. Ovulation rates for the three groups were similar -1.84 .1 .90 , and 1.83 for G27, Pawera, and control groups respectively. Conception rates at the first mating were $93 \%$ for both G27 and Pawera groups and $87 \%$ for the control group. At pregnancy scanning the lambs carried per ewe averaged 1.78, 1.54, and 1.69 for the G27, Pawera, and control groups respectively. The reproductive performance of the Pawera group was not significantly different from that of the other two groups, but in this trial the formononetin level in the Pawera forage was relatively low (for Pawera) at $0.45 \%$.

Results from these two trials clearly demonstrate that not only is it possible to manage the grazing of pure stands of red clover before and during mating so that there is no free equol in the blood of ewes, but that the reproductive performance is also not affected.

Summary and conclusions

1. There is a direct relationship between formononetin intake and blood equol levels.

2. Sheep grazing pure stands of G27, the low formononetin red clover cultivar, can conjugate all equol formed during the first 4 days.

3. Equol is rapidly cleared from the blood after sheep are removed from red clover pastures.

4. Free equol in the blood of sheep grazing red clovers can be prevented by adoption of on/off grazing.

5. The reproductive performance of ewes grazing pure stands of $\mathrm{G} 27$ red clover, before and during mating, is unaffected when on/off grazing is adopted.
These results were obtained with low numbers of sheep per group; however, it is predicted that similar results could also be obtained with much larger flocks. Such a prediction will be tested in on-farm situations.

In the future, producers will be able to take advantage of the potential for increasing stock performance (productive and reproductive) by use of appropriate red clover cultivars and management.

\section{ACKNOWLEDGEMENTS}

Bill Rumball for helpful comments. Funding by Agricom (New Zealand) Ltd. and the NZ Meat Research \& Development Council is gratefully acknowledged.

\section{REFERENCES}

Adams, N.R. 1989. In: Toxicants of plant origin. Vol. IV Phenolics. Clarke. P.R. (eds). Boca Raton, Florida: CRC Press Inc.

Anderson, L.B. 1978. Red clover: a note. Proceedings of the New Zealand GrasslandAssociation 38: 253255.

Anwar, M. 1994. Formononetin content in selected red clover strains and its effects on reproduction in ewes. PhD Thesis Massey University.

Beck, A.B. 1964. The oestrogenic isoflavones of subterranean clover. Australian journal of agricultural research 15: 223-230.

Bennetts, H.W.; Underwood, E.J.; Shier, F.L. 1946. A specific breeding problem of sheep on subterranean clover pastures in Western Australia. Australian veterinary journal 22: 2-12.

Chang T.S. 1961. Reproductive performance of New Zealand Romney sheep grazed on red clover (Trijolium pratense) pastures. Journal of agricultural science 57: 123-127.

Collins, W.J.; Cox R.I. 1985. Oestrogenic activity in forage legumes. pp. 268-276.In: Barnes, R.F.; Ball, P.R.; Brougham, R.W.; Martin, G.C.; Minson, D.J. (eds). Forage for energy-efficient animal production. Springfield, VA: US Department of Agriculture.

Cox, R.I. 1978. Plant estrogens affecting livestock in Australia. pp. 451-464. In: Keeler, R.F.; Kampen, K.R.V.; James, L.F. (eds). Effects of poisonous plants on livestock. New York: Academic Press.

Davies, H.L.; Rossiter, R.C.; Maller, R. 1970. Theeffects of different cultivars of subterranean clover $(T$. subterraneum L.) on sheep reproduction in the southwest of Western Australia. Australian journal of agricultural research 21: 359-369. 
Davies, H.L. 1987. Limitations to livestock production associated with phytocstrogens and bloat. pp. 446 456 In: Wheeler, J.L.; Pearson, C.J.; Robards, G.E. (eds). Temperate pastures - their production, use and management. Melbourne: Australian Wool Corporation/CSIRO Australia.

Francis, C.M.; Millington, A.J. 1965. Varietal variation in the isoflavone content. of subterranean clover: its estimation by a microtechnique. Australian journal of agricultural research Id: 557-564.

Hay, R.J.M.; Ryan, D.L. 1989. A review of 10 years' research with red clovers under grazing in Southland. Proceedings of the New Zealand Association 50: 181-187.

Kelly, R.W.; Hay, R.J.M.; Shackell, G.H. 1979. Formononetin content of 'Grasslands Pawera' red clover and its oestrogenic activity to sheep. New Zealandjournal of experimental agriculture 7: 131134.

Keogh, R.G. 1995. Oestrogens in Pastures. Proceeding of the Nutrition Society of New Zealand 20: 52-61.

Lancashire J.A. 1985. Thedistribution and use of forage legumes in New Zealand. In: Barnes, R.F.; Ball, P.R.; Brougham, R.W.; Marten, G.C.; Minson, (eds). Forage legumes for energy-efficient animal production. D.J. USDA ARS.

Millington, A.J.; Francis, C.M.; McKeown, N.R. 1964. Wether bioassay of annual pasture legumes. II. The oestrogenic activity of nine strains of Trifolium subterraneum L. Australian journal of agricultural research 15: 527-536.
Rossiter, R.C. 1970. Factors affecting the oestrogen content of subterranean clover pastures. Australian veterinary journal 46: 141-144.

Shackell, G.H.; Kelly, R.W.; Johnstone, P.D. 1993. Effect of prolonged exposure of ewes to oestrogenic pasture I. Permanent flock infertility following longterm grazing of red clover('Grasslands Pawera'). dominant pasture. New Zealand journal of agricultural research 36: 451-457.

Shutt, D.A. 1976. The effects of plant oestrogens on animal reproduction. Endeavour 35: 110-I 14.

Shutt, D.A.: Axelsen, A.; Lindner, H.R. 1967. Free and conjugated isoflavones in the plasma of sheep following ingestion of oestrogenic clover.Australian journal of agricultural research 18: 647-655.

Shutt, D.A.; Braden, A.W.H. 1968. The significance of equol in relation to the oestrogenic responses in sheep ingesting clover with a high formononetin content. Australian journalof agriculturalresearch 19: 545-553.

Shutt, D.A.; Weston, R.H.; Hogan, J.P. 1970. Quantitive aspects of phyto-oestrogen metabolism in sheep fed on subterranean clover (Trifolium subterraneum cultivar Clare) or red clover (Trifolium pratense). Australian journal of agricultural research 21: 713722.

Smith, R.S.; Bishop, D.J. 1993. Astred - a stoloniferous red clover. Proceedings of the XVII International Grassland Congress: 421-423. 